\title{
Prinsip Ekstrateritorial Dalam Penegakan Hukum Persaingan Usaha
}

\author{
Asti Rachma Amalya \\ Magister Ilmu Hukum, Fakultas Hukum, Universitas Indonesia \\ Email: a.amalya@gmail.com
}

\begin{abstract}
Economic globalization has led to trade liberalization, many countries embracing a free market where trade and investment are carried out across national borders. As a consequence the boundaries between countries have disappeared, trade and investment restrictions have also declined and the potential for unfair business competition has increased. For this reason, each country seeks to provide protection for its citizens in its territorial territory and bring about conflicts between jurisdictions. The regulations governing the prohibition of monopolistic practices and unfair business competition do not explicitly regulate the application of extraterritorial principles in Indonesia, but KPPU has handled several cases involving foreign business actors and imposed sanctions on business actors who are not domiciled in Indonesia and against acts committed outside of Indonesia. One of the KPPU's decisions stated the Temasek Holdings business group and its subsidiaries had been proven guilty of violating the provisions of Article 27 of the Law on the Prohibition of Monopolistic Practices and Unfair Business Competition and that the KPPU had imposed sanctions. This paper will discuss the application of extraterritorial principles in the context of business competition in Indonesia and see considerations in the relevant KPPU decisions. It will also examine legal obstacles and challenges in the execution of executions because of regulations that have not explicitly governed the application of extraterritorial principles.
\end{abstract}

Keywords: Business Competition Law, Extraterritorial, Law Enforcement, KPPU

Abstrak. Globalisasi ekonomi menyebabkan liberalisasi perdagangan, banyak negara menganut pasar bebas dimana perdagangan dan investasi dilakukan lintas batas negara. Sebagai konsekuensi batas antar negara semakin menghilang, pembatasan perdagangan dan investasi juga makin menurun serta potensi terjadinya persaingan usaha yang tidak sehat meningkat. Untuk itu masing-masing negara berusaha untuk memberikan perlindungan terhadap warga negaranya didalam wilayah teritorialnya dan memunculkan konflik antar yurisdiksi. Regulasi yang mengatur larangan praktek monopoli dan persaingan usaha tidak sehat belum secara tegas mengatur tentang penerapan prinsip ekstrateritorial di Indonesia namun KPPU telah menangani beberapa kasus yang melibatkan pelaku usaha asing dan menjatuhkan sanksi kepada pelaku usaha yang tidak berdomisili di Indonesia dan terhadap perbuatan yang dilakukan di luar wilayah Indonesia. Salah satu putusan KPPU menyatakan kelompok usaha Temasek Holdings beserta anak perusahaannya telah terbukti bersalah melanggar ketentuan Pasal 27 Undang-Undang Tentang Larangan Praktek Monopoli dan Persaingan Usaha Tidak Sehat dan telah KPPU telah menjatuhkan sanksi. Tulisan ini akan membahas penerapan prinsip ekstrateritorial dalam konteks persaingan usaha di Indonesia dan melihat pertimbangan dalam putusan KPPU yang terkait. Selain itu juga akan menelaah hambatan hukum serta tantangan dalam pelaksanaan eksekusi karena regulasi yang belum secara tegas mengatur penerapan prinsip ekstrateritorial.

Kata Kunci: Hukum Persaingan Usaha, Ekstrateritorial, Penegakan Hukum, KPPU

\section{PENDAHULUAN}

Saat ini kita menjadi saksi perkembangan globalisasi ekonomi yang mengalami peningkatan secara pesat dan meluas. Sebagai akibat dari liberalisasi perdagangan, batas antar negara semakin menghilang, pembatasan perdagangan dan investasi juga makin menurun. Pada saat yang sama peran dari perusahaan multinasional yang menjalankan aktivitas 
bisnis lintas batas negara menjadi semakin penting, bahkan menjadi dominan pada beberapa sektor. Dalam aktivitas bisnis batas antara negara semakin menghilang, sehingga hampir tiada batas terlihat, membawa konsekuensi tersendiri secara hukum dimana masing-masing negara berusaha untuk memberikan perlindungan terhadap warga negaranya didalam wilayah teritorialnya. Hukum diperlukan untuk mengatur setiap aspek kehidupan bermasyarakat, termasuk dalam pembangunan ekonomi dalam mewujudkan kesejahteraan sosial. Hukum diperlukan untuk mencegah timbulnya konflik karena sumber-sumber ekonomi terbatas di satu pihak dan di pihak lain tidak terbatasnya permintaan atau kebutuhan akan sumber ekonomi. Menurut Mustafa Kamal Rokan, saat ini terdapat kecenderungan banyak negara menganut pasar bebas dimana pelaku usaha secara bebas dapat memenuhi kebutuhan konsumen dengan memberikan produk yang beragam sekaligus efisien. Kebebasan pasar dalam sistem ini tidak jarang membuat pelaku melakukan perbuatan yang membentuk struktur pasar monopolistik atau oligopolistik. Hal tersebut merupakan perwujudan dari kondisi persaingan usaha yang tidak sehat.

Pada hakikatnya pelaku usaha dalam menjalankan usahanya selalu bersaing, baik yang dilakukan secara positif atau negatif. Persaingan usaha yang dlakukan secara negatif atau sering diistilahkan sebagai persaingan tidak sehat akan berakibat pada: (1) matinya atau berkurangnya persaingan antar pelaku usaha; (2) timbulnya praktik monopoli dimana pasar dikuasai hanya oleh pelaku usaha tersebut; (3) bahkan kecenderungan pelaku usaha untuk mengeksploitasi konsumen dengan cara menjual barang yang mahal tanpa kualitas yang memadai. Oleh karena itu kegiatan bisnis di dalam negeri diatur oleh ketentuan hukum nasional maupun perjanjian internasional yang dibuat oleh pelaku bisnis dalam negeri dengan pelaku bisnis dari luar negeri. Dalam hubungan dengan pelaku bisnis asing dibatasi oleh aturan yang telah disepakati dalam perjanjian internasional seperti GATT/WTO. Namun demikian saat ini belum ada suatu peraturan internasional yang mendasari dan mengikat mengenai kebijakan penerapan hukum persaingan usaha sehingga negara-negara di dunia menerapkan hukum negaranya masingmasing terhadap pelaku usaha asing. Di sisi lain, persaingan dalam dunia usaha merupakan hal yang biasa terjadi, bahkan dapat dikatakan merupakan conditio sine qua non atau persyaratan mutlak bagi terselenggaranya ekonomi pasar, walaupun diakui bahwa adakalanya persaingan usaha itu sehat dan dapat juga tidak sehat. Hal tersebut menimbulkan konflik diplomatik antar yurisdiksi seperti halnya yang terjadi di Amerika Serikat dan negara lain karena penerapan hukum anti persaingan usaha Amerika Serikat dengan negara lain.

Di Indonesia sendiri juga telah memasuki masyarakat pasar bebas sehingga dalam perdagangan juga melibatkan masyarakat regional maupun internasional. Pasal 33 ayat (1) UUD 1945 menghendaki perekonomian Indonesia yang pro persaingan yang dapat mendorong perekonomian yang kondusif bagi rakyat Indonesia. Pasal 33 ayat (1) UUD 1945 mengisyaratkan perlunya restrukturisasi dan reformasi ekonomi melalui penyelenggaraan perekonomian yang berdasarkan demokrasi ekonomi. Restrukturisasi ekonomi diperlukan untuk mewujudkan keadilan ekonomi atau pemerataan ekonomi untuk menghindari polarisasi ekonomi. Dalam konteks persaingan usaha kebijakan yang dibuat oleh pemerintah dapat memberikan kesempatan yang sama dalam kegiatan usaha, bersaing secara sehat.

Undang-Undang No. 5 Tahun 1999 tentang Larangan Praktek Monopoli dan Persaingan Usaha Tidak Sehat saat ini dalam Pasal 1 angka 5 mengatur batasan pelaku usaha yang menjadi obyek undang-undang diatur sebagai berikut: "Pelaku usaha adalah setiap orang perorangan atau badan usaha, baik yang berbentuk badan hukum atau bukan badan hukum yang didirikan dan berkedudukan atau melakukan kegiatan dalam wilayah hukum negara Republik Indonesia, baik sendiri maupun bersamasama melalui perjanjian, menyelenggarakan 
berbagai kegiatan usaha dalam bidang ekonomi."Pengertian pelaku usaha dalam undang-undang tersebut relatif mencakup segala jenis dan bentuk usaha, tanpa memperhatikan sifat badan hukumnya, sepanjang pelaku usaha tersebut menjalankan kegiatannya di wilayah hukum Negara Republik Indonesia. Hal ini berbeda dengan ketentuan Hukum Persaingan Usaha di berbagai negara seperti Amerika, Uni Eropa dan Australia, maupun ketentuan hukum persaingan usaha di negara-negara Asia, seperti ketentuan hukum persaingan usaha di Jepang, Korea Selatan dan Singapura, dimana subjek Hukum Persaingan Usaha bukan hanya pelaku usaha di dalam negeri, tetapi juga berlaku bagi pelaku usaha di luar negeri yang berdampak terhadap perekonomian dalam negeri. Bahkan Hukum Antitrust Amerika misalnya, sebagaimana dinyatakan oleh Areeda, bahwa hukum Antitrust Amerika dapat memeriksa seseorang tanpa melihat personal jurisdiksi dari pelaku tersebut. Kondisi ini tentunya merugikan posisi Indonesia dalam perdagangan internasional dimana Indonesia dapat saja diadili di negara lain namun tidak sebaliknya, Indonesia tidak dapat mengadili perusahaan di luar negeri yang melanggar ketentuan terkait persaingan usaha di Indonesia.

Dengan kegiatan perekonomian yang melampaui batas antara negara, seyogyanya hukum Indonesia juga mampu mengiringi. Implementasi atas suatu aturan dapat dilakukan tanpa mengenal batas. Termasuk yang terkait dengan penegakan aturan hukum terkait persaingan usaha. Sangat mungkin pelanggaran atas prinsip anti persaingan usaha tidak sehat tidak dilakukan di Indonesia namun memiliki impact cukup dalam di dalam negeri. Direktur Eksekutif Lembaga Kajian Persaingan dan Kebijakan Usaha Fakultas Hukum Universitas Indonesia (LKPU FHUI) yang juga merupakan salah satu perumus Naskah Akademik RUU Larangan Praktek Monopoli dan Persaingan Usaha Tidak Sehat, Ditha Wiradiputra, mengatakan Indonesia telah memasuki masyarakat pasar bebas, sehingga cakupan praktik pasar dan perekonomian pasti melibatkan masyarakat regional maupun internasional. Perkembangan tersebut berdampak pada sistem hukum persaingan usaha. Dampak ekonomi kartel dan perilaku anti persaingan pada perusahaan dengan kekuatan pasar dan merger tidak dibatasi oleh batas-batas nasional sehingga sangat mungkin bagi beberapa pelaku usaha untuk mengoperasikan kartel dan memiliki pengaruh signifikan di seluruh dunia. Oleh karena itu, dibutuhkan instrumen pengaturan yang bisa mengakomodir kebutuhan tersebut. Melalui penerapan yurisdiksi atau prinsip ekstrateritorial. Konsep penyempurnaan UU No. 5 Tahun 1999 memuat secara spesifik penambahan pengaturan terhadap lingkup pelaku usaha yang didirikan dan berkedudukan di luar wilayah hukum Negara Republik Indonesia dan menjalankan praktik anti persaingan usaha yang berdampak pada perekonomian nasional. Namun demikian hingga saat ini rancangan undang-undang tersebut belum digulirkan untuk masuk dalam pembahasan program legislasi nasional (Prolegnas).

Otoritas persaingan usaha di Indonesia yakni Komisi Pengawas Persaingan Usaha (KPPU) merupakan suatu lembaga independen yang dibentuk untuk mengawasi pelaku usaha dalam menjalankan kegiatan usahanya agar tidak melakukan praktek monopoli dan/atau persaingan usaha tidak sehat. KPPU tentunya turut andil dalam penegakan hukum prinsip ekstrateritorialitas dalam perdagangan lintas batas negara. KPPU juga terlibat dalam berbagai perundingan kerjasama perdagangan Indonesia dengan beberapa negara atau organisasi internasional misalnya Jepang, Australia, Selandia Baru, ASEAN, OPEC dan lain sebagainya. Selain itu juga KPPU mengambil andil dalam penegakan hukum persaingan usaha terhadap kasus-kasus dengan pelaku usaha yang tidak berada di wilayah Indonesia namun turut ambil bagian dalam kegiatan usaha yang berlangsung atau dilaksanakan di Indonesia. Salah satu contoh konflik terkait yurisdiksi pada beberapa dekade antara lain terjadi antara Amerika Serikat dengan beberapa negara lain terkait aplikasi prinsip ekstrateritorial oleh 
ketentuan anti persaingan usaha Amerika Serikat di luar negeri. Konflik yang muncul menyebabkan friksi antara Amerika Serikat dan negara lain. Di Indonesia sendiri dapat mengacu pada kasus VLCC Pertamina dan Temasek. Pada tulisan ini akan disampaikan bagaimana implementasi prinsip ekstrateritorialitas dan pelaksanaan kewenangan KPPU. KPPU pada kasus dimaksud menjatuhkan sanksi pada pelaku usaha yang berdomisili hukum di luar wilayah Negara Republik Indonesia ditengah cakupan regulasi yang masih terbatas mengatur pelaku usaha yang berdomisili atau melakukan kegiatan di wilayah Indonesia. Dapat dilihat bahwa atas putusan yang melibatkan pelaku usaha asing mengalami kesulitan dalam eksekusinya. Selain itu juga pada tulisan ini juga akan melihat bagaimana negara lain mengimplementasikan prinsip ekstrateritorialitas. Sehingga dengan demikian dapat dilihat apakah dukungan regulasi yang saat ini ada telah cukup membela kepentingan Indonesia dalam perdagangan internasional ataukah diperlukan penyempurnaan.

Berdasarkan uraian di atas maka tulisan ini mencoba membahas penegakan prinsip ekstrateritorial dalam hukum persaingan usaha di Indonesia serta kewenangan KPPU terkait dengan penegakan prinsip ekstrateritorial pada beberapa kasus pelanggaran hukum persaingan usaha yang terjadi. Diharapkan dengan tulisan ini penegakan prinsip ekstrateritorialitas dalam penanganan kasuskasus yang muncul dapat didukung dengan regulasi yang lebih tegas dan memberikan kepastian hukum.

\section{METODE PENELITIAN}

Penulisan ini akan menggunakan metode penelitian normatif. Penelitian dilakukan dengan melakukan penelusuran terhadap bahan hukum antara lain peraturan perundang-undangan diantaranya UU No. 5 Tahun 1999, Peraturan Mahkamah Agung Republik Indonesia Nomor: 03 Tahun 2005 Tentang Tata Cara Pengajuan Upaya Hukum Keberatan Terhadap Putusan KPPU serta Peraturan KPPU Nomor 1 Tahun 2010 tentang Tata Penanganan Perkaral, buku, jurnal serta artikel ilmiah baik yang dipublikasikan baik didalam negeri maupun luar negeri. Selanjutnya dari sumber yang diperoleh dilakukan analisis dengan menggunakan metode analisa yuridis kualitatif.

\section{HASIL DAN PEMBAHASAN}

\section{Yurisdiksi Negara dan Prinsip Ekstrateritorial}

Pada masa globalisasi hubungan antar negara seolah tanpa batas, tidak dapat terpisah satu sama lain. Untuk dapat mencapai pembangunan dengan hasil yang baik diberbagai sektor suatu negara membutuhkan partisipasi dari negara lain. Selain mengandalkan pinjaman dari luar negeri suatu negara dapat bekerja sama dengan investor asing untuk menanamkan modalnya di dalam negeri. Banyak negara mencari modal luar negeri dan biasanya terkait dengan teknologi dan know-how sebagai elemen penting dalam upaya pembangunan ekonomi nasional. Salah satu upaya Indonesia untuk dapat bekerjasama dengan berbagai negara di dunia adalah dengan menjadi anggota World Trade Organization (WTO). Selain aktivitas negara terdapat juga aktivitas perdagangan internasional di dalam negeri yang melibatkan partisipasi investor luar negeri. Kegiatan ekonomi terus berkembang seiring dengan pesatnya perkembangan teknologi komunikasi, informasi dan edukasi dewasa ini yang memacu semakin intensifnya interaksi antar negara dan antar bangsa di dunia. Transaksi ekonomi hari ini bersifat ekstrateritorial.

Bagi negara berkembang salah satu aktor dalam transaksi bisnis internasional yang memiliki peran signifikan adalah Multi National Corporations atau MNC. Keberadaan MNC di suatu negara dapat berpengaruh besar terhadap proses pembangunan pada suatu negara. Sebab kekuatan MNC bisa sangat besar dalam mendorong pertumbuhan ekonomi di negara tersebut. Ketergantungan banyak negara berkembang terhadap MNC salah satunya karena keunggulan teknologi dan modal yang dimiliki MNC. MNC dengan keunggulan teknologi dan modal yang 
dimilikinya dapat mempengaruhi kondisi ekonomi negara, seperti dalam pembukaan lapangan kerja, akses pasar, transfer teknologi, dan sejenisnya. Setelah perusahaan memutuskan untuk memasuki arena internasional, perusahaan harus membuat pilihan-pilihan yang sesuai untuk mengatur kegiatan bisnis asingnya. Kemudian yang harus dijawab adalah pertanyaan bagaimana yurisdiksi terhadap pelaku usaha ekstrateritorial tersebut.

Yurisdiksi diartikan sebagai kekuasaan dan dalam kaitannya dengan negara, kekuasaan itu merupakan cara atau tindakan yang diambil oleh suatu negara untuk melakukan kekuasaannya baik dalam menentukan peraturan perundang-undangan nasionalnya sendiri maupun untuk memberlakukan peraturan tersebut. Dengan demikian diperlukan hukum internasional yang akan mengatur dimana negara dapat melaksanakan yurisdiksinya dan dalam keadaan dimana negara tidak bisa melaksanakan yursdiksi tersebut sehingga dapat mengurangi adanya pertikaian yang bisa timbul antara negara. Pada umumnya setiap negara mempunyai yurisdiksi secara eksklusif diwilayahnya sendiri tetapi yurisdiksi semacam itu bukanlah merupakan yurisdiksi yang bersifat absolut karena akan tergantung dari pembatasan-pembatasan tertentu yang diatur oleh hukum internasional tersebut. Suatu negara mempunyai kekuasaan sepenuhnya di wilayahnya untuk melaksanakan yurisdiksinya terhadap warganegaranya dan sebaliknya negara itu tidak dapat melaksanakan yurisdiksinya di wilayah negara lain. Namun ada beberapa pengecualian dimana sesuatu negara dapat melaksanakan yurisdiksinya di wilayah negara lain (yurisdiksi ekstrateritorial), walaupun dalam beberapa hal ada pembatasan-pembatasannya. Yurisdiksi ekstrateritorial diartikan sebagai kepanjangan secara semu (quasi extentio) dari yurisdiksi sesuatu negara di wilayah yurisdiksi negara lain. Pada implementasinya penerapan yurisdiksi ekstrateritorial akan menemui sejumlah hambatan ketika berhadap-hadapan dengan yurisdiksi negara lain.
Dalam konteks persaingan usaha, bersifat juga ekstrateritorial karena pelaku usaha dapat diminta pertanggungjawaban atas tindakan yang dilakukan oleh pelaku usaha lain sebagai satu kesatuan ekonomi meski salah satu pelaku usaha beroperasi di luar yurisdiksi hukum persaingan usaha suatu negara. Prinsip ekstrateritorialitas dalam hukum persaingan usaha pertama kali diperkenalkan dalam hukum persaingan usaha Amerika Serikat pada masa berkembangnya "effects doctrine" dalam antitrust law. Dimana setiap pelaku anti persaingan di Amerika Serikat dapat dijerat hukum persaingan usaha Amerika Serikat atau berada dibawah yurisdiksi hukum Amerika Serikat apabila terbukti menimbulkan akibat berupa monopoli atau persaingan usaha tidak sehat di wilayah yurisdiksinya baik itu kebetulan atau direncanakan. Dari sisi host country, merupakan yurisdiksi negara untuk mengatur penegakan hukum persaingan yang mencakup yurisdiksi legislatif, eksekutif, yudikatif pada tataran konseptual dapat diterapkan dalam konteks ekstrateritorial. Namun demikian dalam konteks pemberlakuan perlu diuji lebih lanjut apakah akan melanggar kedaulatan negara lain atau tidak. Sebagaimana dinyatakan oleh Mahkamah Internasional (International Court of Justice) dalam opininya dalam Kasus Lotus (Lotus Case) bahwa suatu negara tidak boleh melaksanakan kedaulatannya dalam bentuk apapun di dalam wilayahnya kecuali dengan suatu aturan yang memperbolehkannya yang diperoleh dari kebiasaan internasional atau dari suatu konvensi.

Dalam mencapai tujuan pembangunan ekonomi di Indonesia sebagaimana mandat UUD 1945 khususnya Pasal 33, persaingan usaha yang sehat merupakan salah satu syarat terselenggaranya ekonomi pasar yang dapat memberikan keuntungan bagi pelaku usaha maupun konsumen. Negara dalam hal ini berperan atas terselenggaranya persaingan usaha yang sehat melalui pembentukan peraturan perundang-undangan yang menjamin kelancaran jalannya perekonomian yang memuat larangan 
penindasan golongan yang kuat terhadap golongan yang lemah. Negara juga berperan dalam pembentukan lembaga yang membantu penegakan peraturan perundangundangan tersebut. Peningkatan aktivitas perdagangan lintas batas di Indonesia menyebabkan Indonesia masuk pada era ekonomi internasional yang terintegrasi, sebagai contoh pada tahun 2015 telah dimulai pasar tunggal ASEAN yang memungkinkan transportasi barang, modal, dan tenaga kerja di antara negara-negara Kawasan Asia Tenggara. Hal tersebut tentunya mendatangkan tantangan tersendiri bagi hukum persaingan usaha. Sangat mungkin bagi beberapa pelaku usaha untuk mengoperasikan kartel dan memiliki pengaruh signifikan di seluruh dunia. Untuk dapat berbisnis di Indonesia, pelaku usaha yang berasal dari luar teritorial Indonesia harus membentuk suatu perseroan di Indonesia. Sebagaimana penjelasan di atas bahwa Indonesia sebagai negara berkembang membutuhkan kehadiran MNC masuk ke dalam negeri. Dengan masuknya MNC sebagai investor dapat menambah pasokan modal selain dari kredit yang diberikan perbankan maupun pinjaman luar negeri mengingat besarnya biaya yang dibutuhkan untuk menggerakkan ekonomi untuk mencapai pertumbuhan yang setinggitingginya untuk kemakmuran rakyat. Dengan demikian sebagaimana prinsip yurisdiksi teritorial berlaku hukum host country terhadap pelaku usaha yang berada di Indonesia artinya pelaku usaha asing yang melakukan kegiatan usaha di Indonesia tunduk pula pada regulasi persaingan usaha di Indonesia. Demikian halnya pemegang saham yang berada di luar negeri, mengingat saham yang dikuasai berada dalam lingkup teritori Republik Indonesia. Hal tersebut sesuai dengan doktrin Single Economic Entity Doctrine. Doktrin ini mengakui adanya hubungan antara holding company atau perusahaan induk dan anak perusahaan sebagai entitas ekonomi yang saling terhubung. Dengan demikian anak perusahaan tidak memiliki independensi terhadap induk perusahaan untuk menentukan arah kebijakan perusahaan.
Doktrin single economic entity yang digunakan dalam perkara-perkara tersebut memang pernah diterapkan dalam beberapa kasus persaingan usaha di berbagai negara. Namun, penerapan single economic entity seringkali dihadapkan pada prinsip dasar badan hukum sebagai entitas hukum yang terpisah (separate legal entity). Karakteristik utama atas kedudukan badan hukum sebagai separate legal entity adalah mengenai adanya pemisahan yang tegas antara pengelolaan perusahaan dengan kekuasaan para pemiliknya. Dari perspektif hukum perusahaan anak perusahaan memiliki status badan hukum sendiri, yang terpisah dari induk. Sebagai konsekuensinya masingmasing badan hukum, yakni badan hukum induk dan badan hukum anak perusahaan, memegang hak dan kewajiban sendirisendiri. Perusahaan-perusahaan tersebut didirikan dalam bentuk perseroan terbatas sehingga tunduk pada UU No. 40 Tahun 2007 tentang Perseroan Terbatas (UUPT). UUPT menegaskan dianutnya prinsip separate legal entity dalam Pasal 3 ayat (1) UUPT sebagai berikut: "Pemegang saham perseroan tidak bertanggung jawab secara pribadi atas perikatan yang dibuat atas nama perseroan dan tidak bertanggung jawab atas kerugian perseroan melebihi saham yang dimiliki". Dengan menyandang hak dan kewajiban sendiri-sendiri, maka badan hukum asing yang merupakan induk dari anak perusahaan yang berbadan hukum di Indonesia tidak bertanggung jawab atas perikatan yang dibuat oleh perusahaan yang berkegiatan langsung di Indonesia. Terhadap induk dan anak perusahaan yang berbentuk Perseroan Terbatas, Undang-Undang 40 Tahun 2007 masih mempertahankan pengakuan yuridis terhadap status badan hukum induk dan anak perusahaan sebagai subyek hukum mandiri, walaupun terdapat keterkaitan antara induk dan anak perusahaan. Berdasarkan pendekatan ini kerangka pengaturan perusahaan group yakni induk dan anak perusahaan di Indonesia menggunakan pendekatan Perseroan Tunggal. 


\section{Penegakan Prinsip Ekstrateritorial Dalam Kasus}

Salah satu kasus yang terjadi di Indonesia terkait dengan penerapan prinsip ekstrateritorial dalam hukum persaingan usaha dapat diuraikan pada kasus Temasek. Temasek Holdings yang berdiri pada tahun 1974 merupakan perusahaan besar dari Singapura. Dua anak perusahaannya, yakni Singapore Telecomunication Ltd. (SingTel) dan Singapore Technologies Telemedia Pte.Ltd. (STTelemedia) memiliki saham di dua perusahaan telekomunkasi di Indonesia. SingTel saat ini memiliki 35\% saham di PT. Telkomsel dan STTelemedia menguasai $40,77 \%$ saham di PT. Indosat. Kedua perusahaan tersebut $100 \%$ sahamnya dimiliki Temasek. Padahal, pangsa pasar telepon seluler di Indonesia didominasi oleh PT. Telkomsel dan PT. Indosat, hingga 84,4\%. Dengan penguasaan terhadap dua operator dengan share market terbesar di Indonesia itu, lembaga riset indeks menghitung, Temasek diperkirakan menguasai 89,61\% pangsa pasar industri telekomunikasi di Indonesia. Hal tersebut menunjukkan adanya persaingan usaha tidak sehat.

Pada setiap industri akan selalu ada pelaku usaha yang dominan dan beberapa pelaku usaha yang lebih kecil. Pelaku usaha dominan adalah pelaku usaha yang mempunyai pangsa besar dalam pasar, yang dapat mempengaruhi harga pasar dengan memperbanyak produksinya. Yang dimaksud posisi dominan dalam Pasal 1 angka (4) UU No. 5 Tahun 1999 adalah keadaan dimana pelaku usaha tidak mempunyai pesaing yang berarti di pasar bersangkutan dalam kaitan dengan pangsa pasar yang dikuasai atau pelaku usaha mempunyai posisi tertinggi di antara para pesaingnya di pasar bersangkutan dalam kaitan dengan kemampuan keuangan kemampuan akses pada pasokan atau penjual serta kemampuan untuk menyesuaikan pasokan atau permintaan barang atau jasa tertentu.

Pemilikan saham mayoritas pada beberapa perusahaan dilarang, karena hal tersebut dapat mengakibatkan terjadinya praktik monopoli maupun persaingan usaha tidak sehat yang ditandai dengan terciptanya posisi dominan yang pada gilirannya akan merugikan masyarakat. Demikian pula dilarang pendirian beberapa perusahaan yang memiliki kegiatan usaha yang sama pada pasar bersangkutan yang sama apabila hal itu mengakibatkan terciptanya posisi dominan. Dampak dari kegiatan pemilikan saham mayoritas atau pendirian beberapa perusahaan pada pasar bersangkutan yang sama terjadinya "pengendalian" yang menyebabkan "posisi dominan" yang merupakan unsur utama dari larangan pemilikan saham mayoritas maupun pendirian beberapa perusahaan yang memiliki kegiatan usaha usaha yang sama, sehingga apabila unsur utama tersebut tidak terpenuhi maka pemilikan saham mayoritas maupun pendirian beberapa UU No. 5 Tahun 1999. Adanya pendirian beberapa perusahaan dengan kegiatan usaha yang relatif sama dapat berdampak pada timbulnya posisi dominan. Penggabungan, peleburan beberapa perusahaan dengan pangsa pasar yang telah terbentuk dapat mengakibatkan integrasi secara horizontal yang memunculkan kontrol pada pasar. Pada akhirnya dapat berdampak pada tereduksinya persaingan usaha dan hilangnya inovasi dan upaya efisiensi untuk memenangkan persaingan usaha. Ketentuan pemilikan saham mayoritas yang dilarang atau pendirian beberapa perusahaan yang memiliki kegiatan usaha yang sama dilarang dalam UU No. 5 Tahun 1999 diatur dalam ketentuan Pasal 27, yang menyatakan sebagai berikut "Pelaku usaha dilarang memiliki saham mayoritas pada beberapa perusahaan sejenis yang melakukan kegiatan usaha dalam bidang yang pada pasar bersangkutan yang sama, atau mendirikan beberapa perusahaan yang memiliki kegiatan usaha yang sama pada pasar bersangkutan yang sama, apabila kepemilikan tersebut mengakibatkan:

a. Satu pelaku usaha atau satu kelompok pelaku usaha menguasai lebih dari 50\% (lima puluh persen) pangsa pasar satu jenis barang atau jasa tertentu;

b. Dua atau tiga pelaku usaha atau kelompok pelaku usaha menguasai lebih dari $75 \%$ (tujuh puluh lima persen) 
pangsa pasar satu jenis barang atau jasa tertentu.

Temasek Holdings telah telah melanggar Pasal 27 huruf a Undang-Undang Nomor 5 Tahun 1999 Tentang Larangan Praktek Monopoli dan Persaingan Usaha tidak sehat yaitu mengatur mengenai kepemilikan saham, dan Temasek Holding juga dianggap melanggar Pasal 17 ayat a karena melaksanakan hambatan interkoneksi dan mempertahankan harga tinggi sehingga bersifat anti persaingan. Dalam pembelaannya, kelompok Temasek mendalilkan bahwa KPPU tidak berwenang memeriksa karena perusahaan-perusahaan yang termasuk dalam kelompok Temasek bukanlah didirikan berdasarkan Hukum Indonesia dan tidak beraktivitas secara langsung di Indonesia. Seperti yang dimaksud dengan pengertian pelaku usaha pada Pasal 1 angka 5 Undang-Undang Nomor 5 Tahun 1999 bahwa Temasek Holding merupakan pelaku usaha yang berasal dari luar negeri.

KPPU melalui keputusan No. 7/KPPUL/2007 menepis pembelaan Temasek tersebut dengan menyatakan bahwa Temasek adalah badan usaha sehingga memenuhi unsur "setiap orang" atau "badan usaha" dalam Pasal 1 angka 5 UU No. 5 Tahun 1999 yang berdasarkan prinsip entitas ekonomi tunggal (single economy entity doctrine) dinyatakan dalam relasi induk anak perusahaan, perusahaan anak tidak memiliki indepedensi untuk menentukan arah kebijakan perusahaan. Konsekuensinya adalah pelaku usaha dapat dimintakan pertanggungjawaban atas tindakan yang dilakukan oleh perusahaan lain dalam satu entitas ekonomi dalam hal ini kelompok Temasek. Meskipun pelaku usaha yang pertama beroperasi di luar yurisdiksi hukum persaingan usaha suatu Negara, sehingga sifat ekstrateritorialitas dari penegakan hukum persaingan usaha dapat terpenuhi. KPPU dalam putusannya menyatakan bahwa Temasek Holdings, Pte. Ltd., bersama-sama dengan Singapore Technologies Telemedia Pte.Ltd., STT Communications Ltd., Asia Mobile Holding Company Pte.Ltd., Asia Mobile Holdings Pte. Ltd., Indonesia
Communications Limited., Indonesia Communications Pte. Ltd., Singapore Telecommunications Ltd., Singapore Telecom Mobile Pte. Ltd., terbukti secara sah dan meyakinkan melanggar Pasal 27 ayat a Undang-undang No. 5 Tahun 1999. Majelis komisi juga menghukum masing-masing membayar denda Rp. 25 (dua puluh lima) miliar rupiah. Putusan itu mengakibatkan Temasek Holdings, Pte.Ltd., bersama-sama dengan Singapore Technologies Telemedia Pte.Ltd., STT Communications Ltd., Asia Mobile Holding Company Pte.Ltd., Asia Mobile Holding Pte.Ltd., Indonesia Communications Limited., Indonesia communications Pte.Ltd., Singapore Telecommunications Ltd., Singapore Telecom Mobile Pte.Ltd., untuk menghentikan tindakan kepemilikan saham di PT.Telkomunikasi selular dan PT. Indosat, Tbk., dengan cara melepas seluruh kepemilikan sahamnya di salah satu perusahaan yaitu PT. Telekomunikasi selular atau PT. Indosat Tbk. Dalam waktu paling lama 2 (dua) tahun terhitung sejak putusan ini memiliki kekuatan hukum tetap. Pelepasan kepemilikan saham sebagaimana diatas dilakukan dengan syarat untuk masing- masing pembeli dibatasi maksimal $5 \%$ dari total saham yang dilepas, pembeli tidak boleh terasosiasi dengan Temasek Holdings, Pte.Ltd. maupun dengan pembeli lain dalam bentuk apa pun.

Selain menghukum Temasek, KPPU juga memutuskan PT. Telkomsel bersalah karena melanggar Pasal 17 ayat (1) Undangundang No. 5 Tahun 1999. KPPU memerintahkan PT. Telkomsel membayar denda sebesar Rp.25 miliar dan menurunkan tarif layanannya sebesar $15 \%$ dalam jangka waktu 45 hari dari putusan ini dibuat. Dalam sidang majelis komisi KPPU menemukan fakta kepemilikan silang Temasek di PT. Indosat dan PT. Telkomsel telah menimbulkan kerugian konsumen di industri selular sebesar Rp. 14,7-30,8 triliun selama tahun 2003-2006. KPPU melihat hubungan kepemilikan silang Temasek dengan kerugian di industri selular. KPPU juga mencatat kerugian konsumen mencatat $\mathrm{Rp}$. 9,8-24 triliun per tahun akibat biaya 
interkoneksi yang tinggi. Kerugian terjadi akibat pengaturan tarif oleh PT. Telkomsel tersebut mencapai lebih dari $60 \%$. Berarti pasar yang terbentuk melebihi batas yang diperbolehkan oleh Undang-undang. Dari kondisi itu, KPPU menilai terbentuk kartel pengaturan harga akibat kendali Temasek melalui jajaran direksi dan komisaris yang ditempatkan pada PT. Telkomsel dan PT. Indosat.

Pada kasus Temasek upaya hukum berlanjut sampai pada tingkat kasasi. MA dalam putusan nya menerima dan memperbaiki putusan KPPU dan Pengadilan Negeri Jakarta Pusat dan menyatakan bahwa Temasek bersama anak perusahaan secara sah melanggar Pasal 27 huruf a Undangundang No 5 Tahun 1999 tentang Larangan Praktek Monopoli dan Persaingan Usaha Tidak Sehat. Temasek Holding Pte. Ltd. mengajukan upaya hukum Peninjaun kembali (PK), namun upaya hukum tersebut juga ditolak oleh Mahkamah Agung melalui putusan tanggal 5 Mei 2010. KPPU berpendapat bahwa kelompok Temasek adalah badan usaha sehingga memenuhi unsur setiap orang atau badan usaha sebagaimana dirumuskan Pasal 1 angka 5 UU no 5 tahun 1999. Selain itu badan usaha berdasarkan pada prinsip "single economy entity doctrine" yang menyatakan bahwa hubungan induk perusahaan dengan anak perusahaan dimana anak perusahan tidak mempunyai indepedensi untuk menentukan arah kebijakan perusahaan sehingga sebagai konsekuensinya pelaku usaha dapat dimintakan pertanggungjawaban atas tindakan yang dilakukan oleh pelaku usaha lain dalam satu kesatuan ekonomi, meskipun pelaku usaha tersebut beroperasi diluar yurisdiksi hukum persaingan usaha suatu Negara, sehingga hukum persaingan usaha dapat bersifat ekstrateritorial.

Dalam memberlakukan prinsip ekstrateritorial, KPPU seringkali berargumentasi bahwa dari segi praktek atau penerapan, prinsip bahwa pelaku usaha yang berdomisili di luar wilayah Indonesia terkena ketentuan UU No. 5 Tahun 1999 telah dikukuhkan oleh MA. Putusan MA yang dimaksud KPPU dapat dilihat pada putusan beberapa kasus terkait prinsip ekstrateritorial dalam hukum persaingan usaha antara lain putusan Mahkamah Agung No. Nomor 04/K/KPPU/2005 membenarkan Putusan KPPU 07/KPP-L/2004 tentang kasus penjualan VLCC oleh Pertamina. Dalam Perkara VLCC, Goldman Sach Pte. (Singapura) diputus terbukti secara sah dan meyakinkan melanggar Pasal 19 huruf d dan Pasal 22 UU No. 5 Tahun 1999 dan Frontline Ltd. (Kepulauan Bermuda) melanggar Pasal 22 UU No. 5 Tahun 1999 karena telah bersekongkol dengan PT Pertamina dalam penjualan tanker VLCC. KPPU juga menyatakan bahwa Toray Advanced Materials Korea Inc. (Korea Selatan) terbukti melanggar Pasal 29 UU No. 5 Tahun 1999 juncto Pasal 6 PP No. 57 Tahun 2010 karena memiliki aset melebihi jumlah tertentu sebagaimana diatur dalam PP 57 Tahun 2010, namun terlambat melakukan pemberitahuan ke KPPU. Melalui putusanputusan KPPU yang telah dikuatkan oleh MA, KPPU meyakini bahwa MA memiliki posisi yang sama dengan KPPU dalam menerapkan pengertian pelaku usaha terhadap badan usaha yang didirikan dan berkedudukan di luar negeri, serta pengertian melakukan kegiatan usaha di Indonesia, yaitu bahwa kegiatan yang dimaksud tidak perlu dilakukan secara langsung oleh badan usaha tersebut, namun dapat juga dilakukan melalui pihak lain yang terpisah secara badan hukum.

Dari beberapa contoh kasus di atas, jika ditelaah pengaturan dalam UU No. 5 Tahun 1999 maka pasal tersebut tidak mengatur secara khusus terkait hubungan antara induk perusahaan atau pemegang saham signifikan berupa badan usaha asing dengan perusahaan yang berkegiatan langsung di Indonesia. Pasal 1 angka 5 UU No. 5 Tahun 1999 mengatur jangkauan penerapan wilayah berlakunya, dimana undang-undang hanya berlaku untuk pelaku usaha yang berkedudukan atau yang melakukan kegiatan usahanya di wilayah Negara Republik Indonesia. Frasa yang berbunyi "yang didirikan dan berkedudukan dalam wilayah hukum negara Republik Indonesia" menunjukkan bahwa berlakunya 
UU No.5 Tahun 1999 menganut prinsip teritorial subjektif sedangkan frasa "melakukan kegiatan usaha dalam wilayah hukum negara Republik Indonesia" menunjukkan prinsip teritorial objektif. Dengan demikian cakupan pelaku usaha menurut pengaturan pasal ini diatur secara akumulatif, yaitu terbatas pada badan usaha yang didirikan dan berkedudukan atau melakukan kegiatan usaha di wilayah negara Republik Indonesia. Ketiadaan pengaturan dalan UU No.5 Tahun 1999 yang mengatur secara tegas pelaksanaan prinsip ekstrateritorial akan terus menimbulkan ketidakpastian dalam penanganan permasalahan yang melibatkan pelaku usaha yang tidak didirikan dan tidak berkedudukan di Indonesia karena kepastian hukum menuntut penegakan aturan sebagaimana bunyi ketentuan. UU No.5 Tahun 1999 juga tidak mengatur single economy entity doctrine maupun separate legal entity. Sehingga dalam implementasi hukum persaingan usaha tidak dapat mengesampingkan aturan dalam UUPT yang secara tegas mengatur separate legal entity terlebih lagi jika pengesampingan aturan tersebut dilakukan agar dapat menjatuhkan sanksi terhadap badan usaha asing yang tidak memiliki kantor perwakilan di Indonesia.

$$
\text { Dalam penerapan prinsip }
$$

ekstrateristorial KPPU sering menggunakan argumentasi bahwa KPPU mengacu pada putusan MA terdahulu, misalnya putusan Mahkamah Agung dalam perkara Divestasi Kapal Tanker Pertamina. Selain itu KPPU juga berargumentasi bahwa prinsip ekstrateristorial juga telah diadopsi oleh beberapa negara. KPPU mencontohkan praktek yang terjadi di Amerika Serikat. KPPU menyampaikan "Kasus pertama mengenai penerapan ekstrateritorial di Amerika Serikat terjadi tahun 1909 dalam American Banana Co. v. United Fruit Co., 213 U.S. 347 (1909) yang pada awalnya dimaknai secara sempit. Mahkamah Agung Amerika Serikat dalam putusannya menyatakan: "... the general and almost universal rule is that the character of an act as lawful or unlawful must be determined wholly by the law of the country where the act was done". Doktrin Mahkamah Agung Amerika Serikat tersebut kemudian berkembang sebagaimana terlihat dalam putusan berikutnya dalam perkara United States v. Aluminum Co. of Am., 148 F.2d 416 (2d Cir. 1945) yang menolak doktrin American Banana dan menyatakan tindakan pihak asing yang berdampak terhadap impor Amerika Serikat adalah termasuk dalam pengaturan Sherman Act. Dalam pertimbangannya, Hakim menyatakan: “... any state may impose liabilities, even upon persons not within its allegiance, for conduct outside its borders that has consequences within its borders which the state reprehends". Putusan inilah kemudian yang dikenal sebagai "effect doctrine" dalam penerapan ekstrateritorialitas hukum persaingan AS."

Penggunaan acuan keputusan terdahulu dan penerapan doktrin dalam hukum persaingan usaha di Amerika Serikat tidak dapat terus menerus dijadikan justifikasi untuk mengkategorikan badan usaha asing yang tidak memiliki kantor perwakilan di Indonesia sebagai Pelaku Usaha dalam UU No. 5 Tahun 1999. Sumber hukum utama di Indonesia adalah peraturan perundangundangan, sebagaimana negara yang berkiblat pada hukum Eropa Kontinental. Sistem hukum yang dianut di Indonesia tentunya juga berbeda dengan sistem hukum yang dianut oleh Amerika Serikat atau negara-negara anglo saxon yang menjadikan yurisprudensi atau putusan hakim terdahulu sebagai sumber hukum.

Dengan melihat proses argumentasi dalam pengambilan keputusan atas kasus yang melibatkan pelaku usaha asing terkait penegakan hukum persaingan usaha maka yang paling dibutuhkan adalah adanya perluasan yurisdiksi sehingga peraturan perundang-undangan terkait hukum persaingan usaha dapat berlaku juga bagi pelaku usaha yang berada di negara lain. Selain itu juga perlu diakomodir pengaturan dengan doktrin efek sehingga dapat menjerat tindakan yang dilakukan diluar wilayah Indonesia namun memiliki dampak anti persaingan usaha terhadap pasar Indonesia dan mempengaruhi pencapaian tujuan 
pembangunan perekonomian di Indonesia. Penyempurnaan atas UU No. 5 Tahun 1999 menjadi penting untuk dilakukan untuk secara eksplisit mengatur cakupan pelaku usaha yang merupakan holding company atas perusahaan di Indonesia. Pada rancangan undang-undang UU No.5 Tahun 1999 terlihat definisi pelaku usaha telah diperluas menjadi sebagai berikut: "Pelaku Usaha adalah setiap orang perorangan atau badan usaha, baik yang berbentuk badan hukum atau bukan badan hukum yang didirikan dan berkedudukan atau melakukan kegiatan baik di dalam maupun di luar wilayah hukum Negara Republik Indonesia yang mempunyai dampak terhadap perekonomian Indonesia, baik sendiri maupun bersama-sama melalui perjanjian, menyelenggarakan berbagai kegiatan usaha di bidang ekonomi." Rancangan penyempurnaan undang-undang yang telah disusun sejak tahun 2014 telah masuk dalam Program Legislasi Nasional tahun 2020-2024. Dengan pelaksanaan transaksi dan perdagangan yang terus berjalan dan tidak bisa dihentikan, potensi pelanggaran hukum persaingan usaha terus menghantui sehingga dibutuhkan seharusnya penyelesaian pengesahan rancangan undangundang dimaksud seyogyanya menjadi prioritas.

\section{Kewenangan KPPU Dalam Penegakan Prinsip Ekstrateritorial}

Pada masa lalu ekonomi Indonesia diwarnai oleh corak monopolistik hingga pada 5 Maret 1999 disahkanlah UU No.5 Tahun 1999 dimana pada Pasal 30 sampai 37 mengamanatkan dibentuknya suatu komisi independen yang disebut Komisi Pengawas Persaingan Usaha (KPPU). Pasal 1 angka 18 UU No.5 Tahun 1999 mengatur bahwa KPPU merupakan komisi yang dibentuk untuk mengawasi pelaku usaha dalam menjalankan kegiatan usahanya agar tidak melakukan praktik monopoli dan/atau persaingan usaha tidak sehat. KPPU dibentuk berdasarkan amanat Pasal 30 ayat (1) Undang-undang No. 5 Tahun 1999 yang menyatakan "untuk mengawasi pelaksanaan undang-undang ini dibentuk Komisi Pengawas Persaingan Usaha, yang selanjutnya disebut Komisi". Kemudian dalam Pasal 34 ayat (1) Undang-undang No. 5 Tahun 1999 dinyatakan "pembentukan Komisi serta susunan organisasi, tugas, dan fungsinya ditetapkan dengan Keputusan Presiden". Dalam rangka mengawasi pelaksanaan UU No. 5 tahun 1999, Pemerintah telah membentuk KPPU melalui Keputusan Presiden Nomor 75 Tahun 1999 tentang Komisi Pengawas Persaingan Usaha. Selanjutnya Pasal 30 ayat (2) Undangundang No. 5 Tahun 1999 menyatakan bahwa KPPU adalah suatu lembaga independen yang terlepas dari pengaruh dan kekuasaan Pemerintah serta pihak lain. Independensi ini sangat diperlukan mengingat KPPU juga bertugas untuk memutus perkara pelanggaran terhadap UU No. 5 tahun 1999. Namun demikian bukan berarti KPPU dapat melaksanakan tugas sesuai kehendaknya sendiri, karena KPPU mempunyai kewajiban memberikan pertanggungjawabannya kepada Presiden.

KPPU berperan sebagai suatu alternatif penyelesaian sengketa di luar pengadilan sehingga disebut bersifat kuasi yudikatif. Jika dilihat dari jumlah perkara dan putusan yang dibuat oleh KPPU sejak diundangkannya UU No.5 Tahun 1999 dapat dilihat bahwa KPPU telah memperoleh pengakuan terkait perannya dalam penegakan hukum anti monopoli dan persaingan usaha tidak sehat. Dalam penyelesaian perkara persaingan usaha khususnya yang melibatkan pelaku usaha asing, KPPU melalui beberapa putusannya mendasarkan pada tujuan memperbaiki iklim persaingan usaha di Indonesia yang tidak kompetitif. Terhadap putusan KPPU terdapat 3 kemungkinan yaitu:

a. Pelaku usaha menerima keputusan KPPU dan secara sukarela melaksanakan sanksi yang dijatuhkan oleh KPPU. Pelaku dianggap menerima putusan KPPU apabula melakukan upaya hukum dalam jangka waktu yang diberikan oleh UU untuk mengajukan keberatan. Dengan tidak diajukannya keberatan maka putusan KPPU akan memiliki kekuatan hukum tetap dan terhadap putusan tersebut, dimintakan fiat eksekusi kepada Pengadilan Negeri; 
b. Pelaku usaha menolak putusan KPPU dan selanjutnya mengajukan keberatan kepada PN. Dalam hal ini pelaku usaha yang tidak setuju terhadap putusan yang dijatuhkan oleh KPPU maka pelaku usaha dapt mengajukan keberatan ke Pengadilan Negeri;

c. Pelaku usaha tidak mengajukan keberatan, namun menolak melaksanakan putusan KPPU. Dalam hal itu terjadi maka KPPU menyerahkan putusan tersebut kepada penyidik untuk melakukan penyidikan sesuai dengan ketentuan yang berlaku.

Putusan-putusan yang telah diambil KPPU antara lain berupa perintah agar pelaku usaha menghentikan setiap perbuatan yang terbukti melanggar UU No. 5 tahun 1999 sekaligus menjatuhkan sanksi kepada pelaku usaha yang bersangkutan, sehingga keberadaan dan putusan KPPU dapat memberi arah kepada setiap pelaku usaha untuk selalu mematuhi aturan main dalam menjalankan kegiatan usahanya.Tentunya hal tersebut memperlihatkan bahwa putusan yang dibuat mencerminkan norma-norma yang terkandung dalam proses penegakan hukum persaiangan usaha. Namun demikian dengan belum jelasnya aturan terkait penerapan prinsip ekstrateritorial, akan selalu muncul kontra argumen yang menyatakan bahwa KPPU tidak berwenang memeriksa kelompok pelaku usaha asing karena didirikan bukan berdasarkan hukum Indonesia dan tidak melakukan aktivitasnya di Indonesia.

Kewenangan KPPU sesuai dengan Pasal 36 ayat (6) dikatakan bahwa KPPU berhak untuk memutuskan dan menetapkan ada atau tidak adanya kerugian di pihak pelaku usaha lain atau masyarakat, selain itu sesuai dengan Pasal 36 ayat (7) dikatakan bahwa KPPU berhak mengeluarkan putusan kepada pelaku usaha yang diduga melakukan praktek monopoli dan persaingan usaha tidak sehat. Adanya ketentuan ini menyatakan bahwa KPPU berhak untuk melakukan penegakan hukum persaingan usaha tetapi tidak disebutkan secara tegas apakah bisa melakukan penegakan hukum dalam kerangka ekstrateritorial ataupun tidak.
Demikian halnya jika dikaji Peraturan Mahkamah Agung Republik Indonesia Nomor: 03 Tahun 2005 Tentang Tata Cara Pengajuan Upaya Hukum Keberatan Terhadap Putusan KPPU serta Peraturan KPPU Nomor 1 Tahun 2010 tentang Tata Penanganan Perkara, tidak ditemui klausul ekstrateritorialitas penegakan hukum persaingan usaha secara eksplisit. Dengan demikian hal ini menjadi legitimasi bahwa yurisdiksi tugas dan wewenang KPPU adalah wilayah Republik Indonesia saja.

KPPU sebagai otoritas yang berwenang dalam pengawasan pelaku usaha dalam menjalankan kegiatan usahanya, berpandangan bahwa pemegang saham di perusahaan Indonesia tidak dapat disamakan dengan tingkah laku melakukan aktivitas usaha di Indonesia. Selain itu menurut KPPU bahwa perdebatan antara single economic entity dan separate legal entity merupakan hal yang berbeda, dimana single economic entity adalah doktrin ekonomi sedangkan separate legal entity merupakan doktrin dalam hukum perusahaan. Dalam hukum persaingan usaha disampaikan bahwa perusahaan merupakan entitas yang berdiri sendiri tetapi bukan berarti bebas bergerak sendiri, melainkan dikontrol. Sehingga dengan demikian single economic entity bermakna lebih luas daripada separate legal entity. Pendapat KPPU tersebut tercermin dalam beberapa kasus terkait persaingan usaha yang diputuskan KPPU. Sejak berdirinya KPPU pada tahun 2000 terdapat 7 putusan yang dijatuhkan KPPU terhadap badan usaha asing yang tidak didirikan, tidak berkedudukan di Indonesia dan tidak meiliki kantor cabang atau kantor perwakilan di Indonesia. KPPU menerapkan doktrin ini dengan berkaca pada pengalaman di Uni Eropa yang membenarkan The European Commission menerapkan prinsip ini dalam kasus Europemballage and Continental Can v Commission pada tahun 1973 yang kemudian diperkuat oleh Mahkamah Agung Eropa (Eurpean Court of Justice) dan menjadi yurisprudensi bagi perkara persaingan usaha selanjutnya. Perlu diingat bahwa Indonesia dalam sistem hukumnya tidak wajib tunduk pada preseden 
sebagaimana negara-negara common law di Uni Eropa namun tunduk terhadap peraturan perundang-undangan (hukum positif) yang dibentuk oleh lembaga yang memiliki fungsi legislasi. Oleh karena itu, tidak serta merta dengan berdasar pada putusan ini Indonesia dinyatakan menganut prinsip ekstrateritorialitas dalam hukum persaingan usaha.

Dengan dasar hukum yang kurang kuat terkait cakupan subyek hukum dalam UU No. 5 tahun 1999 tentunya akan berpengaruh dalam eksekusi atas putusannya, meskipun telah terdapat putusan yang telah berkekuatan hukum tetap yang menyatakan pelaku usaha asing sebagai pihak yang terbukti melanggar aturan terkait persaingan usaha. Harus disadari bahwa putusan pengadilan di Indonesia hanya berlaku dan berdaya eksekusi di wilayah hukum Indonesia. Sehingga tanpa adanya landasan hukum yang tegas, eksekusi dapat menemui hambatan. Tentunya dalam penegakan hukum persaingan usaha hal ini merupakan hal yang perlu diperbaiki karena tujuan adanya proses beracara di pengadilan bagi penggugat tidak sekedar memenangkan penggugat namun juga harapan akan terlaksananya putusan pengadilan. KPPU dalam kasus Temasek membutuhkan waktu yang cukup lama dalam melakukan eksekusi putusan. Proses eksekusinya sangat tergantung pada itikad baik Temasek dalam hal ini untuk memenuhi kewajibannya. KPPU hanya mengandalkan cara-cara persuasif untuk mendesak Temasek menjalankan putusan Mahkamah Agung misalnya melalui pemberitaan di media massa, bukan melalui suatu mekanisme hukum.

Terkait dengan proses penanganan perkara dan eksekusi dibutuhkan juga adanya dukungan dalam bentuk perjanjian bilateral atau multilateral dengan negara lain terkait penegakan hukum persaingan usaha. Dengan adanya perjanjian dengan negara lain diharapkan pelaksanaan sita atas harta terlapor dapat lebih mudah. Saat ini KPPU harus mencari sendiri daftar aktiva terlapor yang berdomisili di luar negeri. Dengan perjanjian internasional tersebut proses sita atas harta kekayaan terlapor dapat dilakukan secara efisien mengingat pada proses pemeriksaan memiliki batasan waktu. Selain itu juga dapat bekerjasama proses eksekusi atas putusan dapat ditegakkan secara aktif dan dengan lebih mudah. Saat ini KPPU telah melakukan kerjasama dengan beberapa otoritas persaingan usaha di regional Asia Tenggara/ASEAN maupun luar Asia Tenggara, seperti JFTC (Jepang) dan KFTC (Korea). Namun, kerjasama tersebut kerjasama tersebut hanya dalam lingkup notifikasi, pertukaran informasi, dan pelatihan, belum terdapat kerjasama untuk penanganan perkara dan pelaksanaan putusan.

\section{KESIMPULAN}

Prinsip ekstrateritorialitas dalam
hukum persaingan usaha pada era perekonomian yang terintegrasi dengan negara lain seperti saat ini merupakan suatu keniscayaan. Yang paling dibutuhkan adalah perluasan yurisdiksi bagi Indonesia untuk dapat menindak secara tegas pelaku usaha dengan badan hukum Indonesia atau badan hukum asing yang melakukan tindakan anti persaingan usaha di luar wilayah negara Republik Indonesia yang karena tindakannya dapat mengganggu pasar dan perekonomian Indonesia. KPPU sebagai otoritas dalam penegakan hukum persaingan usaha pada dasarnya belum memiliki landasan hukum yang tegas dalam menerapkan prinsip ekstrateritorial dalam penegakan hukum persaingan usaha. Disisi lain penegakan hukum persaingan usaha yang terjadi di luar wilayah yurisdiksi Indonesia menjadi perhatian KPPU terutama jika memiliki pengaruh terhadap perekonomian Indonesia. Sehingga dengan demikian ketegasan pengaturan kewenangan otoritas untuk menegakkan hukum persaingan usaha terhadap pelaku usaha badan hukum asing yang melakukan tindakan di luar negeri, dalam hal ini adalah KPPU, juga penting untuk dimiliki sehingga dapat bertindak secara tegas terhadap pelaku usaha yang melanggar peraturan terkait persaingan usaha di Indonesia.

Selain proses pemeriksaan perkara, hal yang juga penting adalah eksekusi atas 
putusan pengadilan yang sudah berkekuatan hukum tetap. Tentunya pelaku usaha berkeinginan agar ketika beracara di pengadilan tidak sekedar memenangkan perkara, namun juga dapat terlaksananya eksekusi atas putusan pengadilan tersebut. Tanpa adanya landasan hukum yang kuat, KPPU tidak dapat melakukan eksekusi berdasarkan mekanisme hukum karena putusan pengadilan di Indonesia hanya berlaku dan berdaya eksekusi di wilayah hukum Indonesia. Untuk itu dibutuhkan dukungan kerjasama bilateral atau multilateral untuk dapat melaksanakan proses eksekusi yang efisien dan efektif.

\section{SARAN}

Berdasarkan uraian di atas maka dalam penegakan hukum persaingan usaha di Indonesia, Penerbitan penyempurnaan UU No. 5 Tahun 1999 perlu segera dilakukan untuk mencegah multi interpretasi atas bunyi pasal terkait definisi pelaku usaha. Definisi pelaku usaha dalam UU No. 5 Tahun 1999 belum dapat memberikan kepastian hukum ketika terjadi pelanggaran hukum anti persaingan usaha di Indonesia sehingga perlu mengakomodir bahwa yang termasuk Pelaku Usaha adalah meliputi pula cabang, anak perusahaan, atau afiliasi yang dikendalikan langsung atau tidak langsung oleh perusahaan yang bersangkutan. Dengan perluasan definisi pelaku usaha juga perlu didukung dengan pengaturan yang memperkuat posisi KPPU untuk menjerat pelaku usaha asing yang melakukan tindakan anti persaingan usaha di dalam wilayah Indonesia maupun di luar wilayah Indonesia. Pengaturan regulasi yang tegas dapat memberikan landasan bagi KPPU untuk melaksanakan keputusannya dan membuat keputusan yang dibuat memiliki daya paksa bagi pelaku usaha untuk memenuhi kewajibannya.

Kerjasama bilateral dan multilateral dengan negara lain perlu diselenggarakan agar proses pemeriksaan dan eksekusi atas perkara persaingan usaha yang melibatkan pelaku usaha asing dapat dilakukan lebih efektif dan efisien sesuai dengan mekanisme hukum yang berlaku, tidak sekedar melalui prosedur persuasif untuk mendesak pelaku usaha asing memenuhi kewajiban sesuai putusan pengadilan. Kerjasama tersebut mencakup kerjasama antara otoritas untuk mencari aktiva pelaku usaha asing untuk dapat dilakukan sita maupun dalam proses eksekusi putusan persaingan usaha.

\section{DAFTAR PUSTAKA}

AK, Syahmin, Hukum Dagang Internasional, (Jakarta: PT Raja Grafindo Persada, 2006)

Areeda, Phillip, Antitrust Analysis, third edition, 1981

Darmawan, Irma Arimbi, Isis Ikhwansyah, Pupung Faisal, "Cross Border Business Competition: Keabsahan dan Hambatan Penerapan Prinsip Ekstateritorial Dalam Penegakan Hukum Persaingan Usaha di Indonesia", Jurnal Bina Mulia Hukum vol.3, nomor 1, September 2018

Gomes, David M., "Extrateritoriality in Competition Law and Globalization: Square Peg in a Round Hole?", University of Northumbria, 2005

Huzaini, M Dani Pratama "Ekstrateritorialitas Penegakan Hukum Persaingan Usaha Sebuah Keniscayaan", https://www.hukumonline.com/berita/b aca/lt598996a0c114b/ekstrateritorialita s-penegakan-hukum-persaingan-usahasebuah-keniscayaan/, diakses 21 Februari 2020

Iskandar, Verry "Akuisisi Saham oleh Perusahaan Terafiliasi dalam Perspektif Hukum Persaingan Usaha”, Jurnal Persaingan Usaha, 5, Jakarta: Juni 2011

Juwana, Himahanto, "Sekilas tentang Hukum Persaingan dan UU No.5 Tahun 1999", Jurnal Magister Hukum 1 Tahun 1999

Kojima, Takaaki "International Conflicts over the Extraterritorial Application of Competitin Law in a Borderless Economy", USA: Weatherhead Center Harvard University, 2002

Lane, Robert, EC Competition Law, (Harlow: Pearson Education Limited, 2000) 
Lubis, Andi Fahmi (et.al), Hukum Persaingan Usaha, Komisi Pengawas Persaingan Usaha, (Jakarta: 2017)

Miller, Samuel F., "Prescriptive Jurisdiction over Internet Activity: The Need to Define and Establish the Boundaries of Cyberliberty", Indiana Journal of Global Legal Studies, Volume 2, Issue 2, 2003

Mitchell, Andrew D. "Broadening The Vision of Trade and Liberalisation: International Competition Law", World Competition Law and Economic Review Volume 24 Kluwer Law International, 2001

Nugraha, Purna Cita "Penerapan Rezim Extraterritorial Jurisdiction dalam Hukum Siber di Indonesia", Jurnal Opinio Juris Vol.15 Januari-April 2014

Nugroho, Susanti Adi, Hukum Persaingan Usaha di Indonesia, Jakarta: Kencana Prenada Media Group, 2012

Oktaviano, Ahmad Alfa dan Ditha Wiradiputra, "Dampak Prinsip Ekstrateritorial Terhadap Regulasi Merger, Konsolidasi, dan Akuisisi Dalam Hukum Persaingan Usaha di Indonesia", http://www.lib.ui.ac.id/naskahringkas/2 016-06/S56456-

Ahmad\%20Alfa\%20Oktaviano, diakses 25 Februari 2020

Purba, A. Zen Umar "Transnasional Law and IBT Course", Jurnal Hukum Internasional vol.12 no. 2 Januari 2015

Republik Indonesia, Undang-undang Larangan Praktek Monopoli dan Persaingan Usaha Tidak Sehat, UU No. 5 Tahun 1999, LN No, 33 Tahun 1999, TLN No, 3817

Rokan, Mustafa Kamal, Hukum Persaingan Usaha Teori dan Praktiknya di Indonesia, Jakarta: Raja Grafindo Persada, 2012

Sulistiowati, Aspek Hukum dan Realitas Bisnis Perusahaan Group di Indonesia, Jakarta: Erlangga, 2010

Suryokusumo, Sumaryo, "Yurisdiksi Negara vs Yurisdiksi Ekstrateritorial", Jurnal
Hukum Internasional vol 2 Nomor 4 Juli 2005

Syahmin, Hukum Diplomatik Dalam Kerangka Studi Kasus, Jakarta: PT Rajagrafindo Persada, 2008

Usman, Rachmadi, Hukum Persaingan Usaha di Indonesia, Jakarta: Sinar Grafika, 2013

Yani, Ahmad dan Gunawa Widjaja, Seri Hukum Bisnis Antimonopoli, Jakarta: PT Raja Grafindo Persada, 1999 